\title{
Iain STEWART, Raymond Aron and Liberal Thought in the Twentieth Century
}

Henri-Pierre Mottironi

\section{OpenEdition}

1 Journals

Édition électronique

URL : https://journals.openedition.org/ress/7959

DOI : $10.4000 /$ ress.7959

ISBN : $1663-4446$

ISSN : 1663-4446

Éditeur

Librairie Droz

Édition imprimée

Date de publication : 6 décembre 2021

Pagination : 339-342

ISSN : 0048-8046

Référence électronique

Henri-Pierre Mottironi, « lain STEWART, Raymond Aron and Liberal Thought in the Twentieth Century », Revue européenne des sciences sociales [En ligne], 59-2 | 2021, mis en ligne le 01 décembre 2021, consulté le 09 décembre 2021. URL : http://journals.openedition.org/ress/7959; DOI : https://doi.org/ 10.4000/ress.7959

Ce document a été généré automatiquement le 9 décembre 2021.

(c) Librairie Droz 


\title{
Iain STEWART, Raymond Aron and Liberal Thought in the Twentieth Century
}

\author{
Henri-Pierre Mottironi
}

\section{RÉFÉRENCE}

Iain STEWART, 2020, Raymond Aron and Liberal Thought in the Twentieth Century, Cambridge - New York, Cambridge University Press, 304 p.

In 1975 on "Parti Pris", a French radio program, Raymond Aron explained that he was a liberal since he was anti-revolutionary and anti-totalitarian.

I think I am a non-conformist, even if one considers that I have a rather conservative political opinion. In reality, I am essentially an anti-revolutionary [...]. What seems to me fundamental is anti-totalitarianism, the anti-revolution, the two more or less linked and all this goes back to my German experience between 1931 and 1933 when I saw the rise to power of National Socialism [...] today one is either revolutionary or anti-revolutionary. And if one is anti-revolutionary one is liberal and democrat, as I am. (my translation of Raymond Aron's interview by Jacques Paugam on France Culture, "Parti Pris" November $19^{\text {th }} 1975$ [online last consultation 06/15/21: <https://www.franceculture.fr/emissions/les-nuits-defrance-culture/raymond-aron-la-politique-est-amorale-et-dans-un-grand-0>]).

In the light of Iain Stewart's Raymond Aron and Liberal Thought in the Twentieth Century, this quotation is a good illustration of the peculiar relationship of the French intellectual with Liberal thought. By focusing mainly on Aron's intellectual development before the 1950s, the book argues that most of Aron's key ideas stemmed paradoxically from authors and ideas outside the liberal tradition. In fact, whereas in the 1970s Aron defined himself a liberal democrat, he steadfastly refused to claim the mantle of liberalism before the 1950s, by preferring to identify with heterodox socialism and anti-revolutionary currents of thought. 
3 The literature often explains Aron's conversion to political realism, by evoking the author's own recollections of his three years in Germany in the 1930s, which resulted in a neat rupture with his "youthful idealism" (p.30). Stewart shows that this crucial period in Aron's life cannot be summarized merely as a sudden conversion from youthful idealism to mature political realism. His direct witnessing of the rise to power of the Nazi Party was an "eye-opening experience" which nurtured his antitotalitarian views, but it resulted in the intensification of the political realist views he already had in the 1920s. Indeed, during his student's years, Aron evolved in groups of French pacifist and socialist students. Their opinions could be best described as "nonconformist", as they rejected the left-right divide but also philosophically embraced realism-fact which all the more unorthodox concerning pacifism. It is well established that Aron departed from his youthful pacifist views in the aftermath of the fall of the Weimar Republic, but this change is less inconsistent with his past involvement in student's political associations that it might seem at first glance. True to these non-conformist views, in the late 1930s, Aron adopted a paradoxical political posture, by becoming both a staunch anti-fascist, and a fierce critic of organized antifascist movements (p.42).

4 His stay in Germany represented a break, since it took him away from the French political milieu of his youth, and introduced him to the German sociological and philosophical tradition, tradition which was under-represented in French academia at that time. Stewart points out that Aron's studies of German thinkers set the foundations for many famous theories he would develop later, like the end of ideology, or his criticism of French Durkheimian sociological positivism. In particular, his encounter with Max Weber's works on the ethics of responsibility contributed to his break from the pacifist views of one of his mentors, the French philosopher Alain, and led him to adopt an intellectual posture of "statesmanlike prudence". For him, most French intellectuals were out of touch with the realities of political life, because they "failed to consider politics from the viewpoint of the statesman" (p.40).

5 Aron's thought was also durably marked by Wilhelm Dilthey's works and Martin Heidegger's philosophy. From their ideas, in his 1938 Introduction to the Philosophy of History, he developed a conception of social facts as subjective, facts which ought to be interpreted like literary or philosophical texts (p.61-62). This led him to advocate a certain historical relativism, which would have far-reaching implication on the history of French liberalism and, incidentally, on that of existentialism. Coupled with his "statesmanlike prudence" posture, Aron's ideas in Introduction to the Philosophy of History served as a base for his seminal works on ideology and secular religions, ideas which would take an anti-revolutionary and anti-communist turn in his 1955 The Opium of Intellectuals.

6 Aron's strengthened realism did not, however, spur his interest in the liberal tradition in the late 1930s, on the contrary. His vision of a "free State" derived in fact from his intellectual engagement with thinkers like Carl Schmidt, Vilfredo Pareto or Hermann Rauschning whose "ideas towards liberalism and democracy ranged from indifference to profound hostility", as Stewart puts it (p.96). On the one hand, Aron shared with the radical right of the 1930s their criticisms of parliamentarism, and their views on the necessity of a strong executive power. On the other, he believed that popular sovereignty was not an essential feature of democracy, or at least not as paramount as the protection against arbitrary power was for a free polity. But he believed that the 
survival of democratic regimes in the face of totalitarian systems depended on the adoption of some features of totalitarian states, without sacrificing individual liberties (p.132). Paradoxically, these anti-liberal influences brought him to defend a "constitutional-pluralistic" regime, i.e. a representative system with a strong executive power and whose decisions would rest heavily on technical expertise. Although one might see proximities with $19^{\text {th }}$ century liberal elitist views (for instance, François Guizot's ideas on government-see Olivia Leboyer, 2010, "Le souci de l'élite politique chez les libéraux", Raisons politiques, 4, p.75-95), Stewart thoroughly demonstrates that Aron's political views stemmed from outside the liberal tradition.

7 His endorsement of a political system all in all very close to the "liberal bourgeois democracy" was nonetheless not coupled with the advocacy of free-market economy. Like "third way neoliberals", Aron indeed favored a form of State-led economy with a government maintaining a strong connection with technical experts. Yet again, his views on that matter appear to find their sources not in liberal thinkers but in nonMarxist socialist thought. Stewart sees mostly Saint-Simonian inspirations in the economic planning Aron pleaded for, and in his acceptance of the idea of nationalizing key economic sectors (like mines, transports, chemicals or electricity production) (p. 134-135). Moreover, the heterodox Belgian socialist Hendrik de Man's views expressed in Zur Psychologie des Socialismus-book of which Aron published a favorable review in 1931-played an important role on his reflection on a third way between free-market and economic planning.

8 The link between Aron's thought and elitist theorists like Charles Wright Mills and James Burnham, pointed out in Chapter 4, provides readers with useful elements to understand the articulation between constitutional pluralistic government and economic interventionism. Stewart indicates for instance that Burnham's Managerial Revolution and The Machiavellians fueled Aron's reflections of a democracy compatible technocracy (p.160-161). Following Burnham works, he came to the conclusion that the difference between democratic and totalitarian regimes was to be found in the nature of their elites-pluralistic in Democracy and monolithic in totalitarian States. This resulted in Aron's promotion of a polyarchic theory of a free polity similar to Joseph Schumpeter's and Robert Dahl's visions of democracy. Stewart's book, however, says very little on this specific point.

9 Aron's anti-totalitarian and anti-revolutionary engagements led him progressively to preach a form of heterodox liberalism during the Cold War. Whether one prefers to relate it to "Cold War liberalism" or to "Third way neoliberalism" is secondary in order to explain why Aron, who "refused to claim the mantle of liberalism" in the 1940s, started to do so after the war, in spite of the fact that his thought was built on heterodox socialist beliefs and practices.

10 Historians of economic and political thought will appreciate the quality of the argument in chapter 5 and the resort to the concept of "traditionary action"-i.e. an instrumental relationship to the notion of tradition-to solve this enigma. Stewart suggests that Aron's allegiance to liberalism in the 1960s proceeded from a form of instrumentalization of the French liberal tradition in two ways. On the one hand, Aron aligned himself with Montesquieu and Tocqueville to confer what Stewart calls a "cultural legitimacy" to his French school of political sociology. On the other, he "instrumentalized", in a weaker sense, Tocqueville, Constant and Montesquieu as he mobilized writings of these authors and interpreted them in the light of his own 
political, social or methodological concerns of the 1960s. In that regard, Aron's colorful comment of his reaction to May 68 seems to fall in the second category: "I played Tocqueville, which is somewhat ridiculous. But others played Saint-Just, Robespierre or Lenin, which, all things considered, is even more ridiculous" (p.204).

But let us not jump to conclusions here. The book does not claim that Aron's alignment with authors like Tocqueville or Montesquieu was merely opportunistic. As other specialists have shown, Aron found in those authors political considerations which strikingly matched his (José Colen et Élisabeth Dutartre-Michaut [dir.], 2015, The Companion to Raymond Aron, New York, NY, Palgrave Macmillan, chap. 18 and 19, p. 245-274.). Nonetheless, in the French intellectual context of May 68, Aron set a line of interpretation which saw in $18^{\text {th }}$ and $19^{\text {th }}$ century liberal thinkers rich sources of antitotalitarian arguments that could be directed towards radical left French intellectuals like Michel Foucault or Gilles Deleuze (p.222 \& seq.).

Delving directly into Aron's thought during the Cold War, the last chapters might still fall short of the expectations of readers more interested in political science than intellectual history. For instance, very little is said about Aron's views on French Constitutional debates of the $\mathrm{IV}^{\text {th }}$ and $\mathrm{V}^{\text {th }}$ Republic and his thoughts on international affairs. This is all the more regrettable as Stewart's biography provides many elements that would have helped to understand Aron's constitutional ideas and his contribution to the theory of international relations.

These caveats apart, Raymond Aron and Liberal Thought in the Twentieth Century is a cleverly structured and well-written intellectual biography, which greatly enlightens readers on both Aron's thought and his role in the French $20^{\text {th }}$ century revival of liberal studies. All in all, Stewart's study is a major contribution to the history of liberalism, under the light of which Aron's identification with Tocqueville seems all the more apropos as his liberalism is as strange and unusual as that of the author of Democracy in America (Roger C. Boesche, 1981, "The Strange Liberalism of Alexis de Tocqueville", History of Political Thought, 2-3, p. 495-524).

\section{AUTEURS}

\section{HENRI-PIERRE MOTTIRONI}

Université de Neuchâtel 